\title{
AOR
}

Selected Papers of \#AolR2021:

The 22nd Annual Conference of the

Association of Internet Researchers

Virtual Event / 13-16 Oct 2021

\section{CRITICAL CARE \& THE EARLY WEB: ETHICAL DIGITAL METHODS FOR ARCHIVED YOUTH DATA}

Katie Mackinnon

University of Toronto

Web archiving initiatives and organizations are currently engaged in "intervening and shaping the availability of information/media" (Ogden, 2020) through their collection practices as they provide access to parts of the web that have been deleted or abandoned by state and corporate owners. This has significant impact on the future of historical research, as the materials collected will act as an "unprecedently rich primary resource" (Winter, 2017), thus shaping and informing the types of histories we can write. The Internet Archive, one of the most prominent and prolific web archives, has been crawling and collecting materials for the past 20 years with a mission to preserve web history that would otherwise be lost. This approach, however, cannot account for the sensitivity of the materials it has captured. For researchers engaging with web materials in web archives, there are significant ethical and methodological challenges and questions to engaging with web archived collections in the Internet Archive.

For example, GeoCities web pages archived in Internet Archive, like neighborhoods WestHollywood (LGBTQ+) or EnchantedForest (Youth), are a unique and incredibly fruitful resource for studying youth and queer participation in the early web in a way that gives those voices autonomy and agency and are integral resources for writing about digital cultures on the early web. However, there are significant ethical concerns around a researcher's approach to this data. It is imperative that we consider whose stories are being told, who is equipped to tell them, and what kinds of vulnerability and harm we might encounter and nurture when doing so (Cowan, 2020; franzke, et al., 2020; Luka \& Millette, 2018; Lin et al., 2020). Young people's data are particularly subject to commodification, surveillance, and archiving without consent (Grimes \& Chung, 2005; Steeves, 2015; Van Dijck et al., 2018), and researchers who engage with their archived web material have a responsibility to develop better practices of care. One of the biggest challenges in historical web research is grappling with distance between researchers and the researched; websites become defunct, users have grown up and changed names, and communities have splintered and dispersed. Informed consent is nearly never a possibility, and while deploying "contextual integrity" tactics and evaluating the scale of archived web materials are significant ethical developments (Lomborg, 2018; Nissenbaum, 2010; Tiinderberg, 2018), getting in contact with creators 
of digital materials is still an important ethical dimension for many internet researchers (Eichhorn, 2019; Horbinski, 2018; Leurs 2017; Lialina, 2017; Robards \& Lincoln, 2020).

This paper demonstrates an ethico-methodological (Cowan, 2020) approach to working with archived web pages created by young people and collected and stored by the Internet Archive. The Early Internet Memories project explored archives with web materials made by young people throughout 1994-2005 through qualitative, online semistructured interviews. Participants are positioned as co-investigator and analyst of web archival material, enabling simultaneous discovery, memory, interpretation and investigation, as they guided the researcher through a walkthrough of their digital materials collected and stored in web archives (Light, Burgess, Duguay, 2016; Robards \& Lincoln, 2017). This method begins with the person, rather than their data, and is influenced by the conceptual framing of data materials in research on the "right to be forgotten" (Crossen-White, 2015; GDPR, 2018; Tsesis, 2014), digital afterlives (Sutherland, 2020), indigenous data sovereignty and governance (Wemigwans, 2018), and the Feminist Data Manifest-No (Cifor et al, 2019). By exploring experiences and memories of the web while guided through web archives by the creators, we are able to re-center human and move towards a digital justice approach (Gieseking, 2020; Cowan \& Rault, 2020) and a critical feminist ethics of care (Luka \& Millette, 2018) for engaging with historical youth data.

\section{Works Cited}

Cifor, M., Garcia, P., Cowan, T.L., Rault, J., Sutherland, T., Chan, A., Rode, J., Hoffmann, A.L., Salehi, N., Nakamura, L. (2019). "Feminist Data Manifest-No." Retrieved from: https://www.manifestno.com/.

Cowan, T.L. \& Rault, J. (2020). "Heavy Processing for Digital Materials (More Than a Feeling)," Digital Research Ethics Collaboratory, http://www.drecollab.org/risking-it/.

Cowan, T.L. (2020). "X-Reception: Re-mediating Trans- Feminist and Queer Performance Art," in Kathryn Brown (ed), The Routledge Companion to Digital Humanities and Art History. Taylor and Francis.

Crossen-White, H. L. (2015). "Using digital archives in historical research: What are the ethical concerns for a 'forgotten' individual?" Research Ethics, 11, 108 - 119.

Eichhorn, K. (2019). The end of forgetting: growing up with social media. Cambridge, Mass: Harvard University Press.

franzke, aline shakti, Bechmann, Anja, Zimmer, Michael, Ess, Charles and the Association of Internet Researchers. (2020). "Internet Research: Ethical Guidelines 3.0." Retrieved from: https://aoir.org/reports/ethics3.pdf

General Data Protection Regulation (2018). "Right to be Forgotten." https://gdprinfo.eu/issues/right-to-be-forgotten/. Accessed March 10, 2020. 
Gieseking, JJ. (2020). "Privacy in Public: Visualizing the Lives of Trans Youth through Tumblr Posts." Digital Research Ethics Collaboratory, http://www.drecollab.org/privacyin-public/.

Grimes, Sara and Grace Chung. (2005). "Data Mining the Kids: Surveillance and Market Research Strategies in Children's Online Games." Canadian Journal of Communication vol. 30 no. 4 .

Horbinski, A. (2018). Talking by letter: the hidden history of female media fans on the 1990s internet, Internet Histories, 2:3-4, 247-263, DOI: $10.1080 / 24701475.2018 .1500794$

Leurs, K. (2017). "Feminist data studies. Using digital methods for ethical, reflexive and situated socio-cultural research." Feminist Review, 115(1): 130-154.

Lialina, Olia. (2017). "Still There: Templates and Ruins of GeoCities," in Annett Dekker (ed) Lost and Living (in) Archives: Collectively Shaping New Memories. Amsterdam: Valiz.

Light, B., J. Burgess, S. Duguay, (2018). "The walkthrough method: An approach to the study of apps." New Media \& Society, 20(3): 881-900.

Lin, J., I. Milligan, D.W. Oard, N. Ruest, K. Shilton. (2020). "We Could, but Should We? Ethical Considerations for Providing Access to GeoCities and Other Historical Digital Collections." CHIIR '20, March 14-18, Vancouver, BC, Canada.

Luka, M.E. \& Millette, M. (2018). (Re)framing big data: Activating situated knowledges and a feminist ethics of care in social media research. Social Media + Society, JanuaryMarch, 1-10. doi: 10.1177/2056305118768297

Lomborg, S. (2018). "Ethical Considerations for Web Archives and Web History Research," In: eds. Brügger, N. \& Milligan, I. (eds) SAGE Handbook of Web History, pp. 199-219.

Nissenbaum, H. (2010). Privacy in Context: Technology, Policy, and the Integrity of Social Life, Stanford, Stanford University Press.

Ogden, J. (2020). WEB ARCHIVING AS CULTURE: TUMBLR AND THE CULTURAL CONSTRUCTION OF THE ARCHIVED WEB. AoIR Selected Papers of Internet Research, 2020. https://doi.org/10.5210/spir.v2020i0.11294

Robards, B. \& Lincoln, S. (2020). Growing up on Facebook. New York: Peter Lang.

Robards, B. \& Lincoln, S. (2017). "Uncovering longitudinal life narratives: scrolling back on Facebook," Qualitative Research, 17(6): 715-730. 
Steeves, Valerie. (2015). "Now You See Me: Privacy, Technology, and Autonomy in the Digital Age." Current Issues and Controversies in Human Rights, edited by Gordon DiGiacomo, University of Toronto Press, pp.1-31.

Sutherland, T. (2020). "Data, Death, and Dignity: Reflections on Archives and the Digital Afterlife." ICHORA '20, October 26-30, Michigan, USA.

Tiidenberg, K. (2018). "Research Ethics, Vulnerability, and Trust on the Internet". In J. Hunsinger, L. Klastrup, M. Allen (eds.) Second International Handbook of Internet Research (pp. 1-15). Dordrecht: Springer.

Tsesis, A., (2014). "The Right to be Forgotten and Erasure: Privacy, Data Brokers, and the Indefinite Retention of Data," Wake Forest Law Review, Vol. 48, Loyola University Chicago School of Law Research Paper No. 2013-11/30.

Van Dijck, Jose, Thomas Poell and Martijn de Waal. (2018). The Platform Society: Public Values in a Connective World. Oxford Scholarship Online.

Wemigwans, J. (2018). A Digital Bundle: Protecting and Promoting Indigenous Knowledge Online. University of Regina Press. 